ПЕРЕЛІК ВИКОРИСТАНИХ ДЖЕРЕЛ

1. Бир С. Кибернетика и управление производством. - М. : Наука, 1965. - 392 c.

2. Бункина М.К., Семенов А.М. Экономика и психология. На перекрестке наук. - М.: Дело и Сервис, 1999. - 263 с.

3. Вегера С. А. Поведінкова економіка - особлива галузь економічної теорії / Актуал. проблеми економіки. 2004. - № 2. - C. 4-16.

4. Гетьман O.O., Шаповал B.M. Економіка підприємства навч. посіб. - 2ге видання. - К.: Центр учбової літератури, 2010. - 488 с.

5. Глушков В. М. Кибернетика. Вопросы теории и практики. - М. : Наука, 1986. -488 c.

6. Горбонос Ф.В., Черевко Г.В., Павленчик Н.Ф., Павленчик А.О. Економіка підприємства. Київ, Знання 2010, 463 c.

7. Друкер П. Ф. Рынк: как выйти в лидеры: практика и принципы. M. : Book chamber international, 1992. - 354 c.

8. Економічний словник / за ред. Завадського Й.С., Осовської Т.В., Юшкевич О.О. Київ, Кондор 2006, 356 с.

9. Енциклопедія сучасної України. Ел. ресурс http://esu.com.ua/search_articles.php?id=123 99
10. Капленко Г.В. Формування економічної поведінки підприємств: автореф. дис... канд. екон. наук: 08.06.01 /НАН України; Інститут регіональних досліджень. - Л., 2005. - 20 с.

11. Ложкін Г.В., Спасснніков В.В., Комаровська В.Л. Економічна психологія: Навчальний посібник. - К.: ВД «Професіонал», 2004. - 304 с.

12. Прохорова В. В., Проценко В. M., Чобіток В. I. Формування конкурентної стратегії підприємств на засадах інвестування : монографія. Харків: Українська інженерно-педагогічна академія, 2015. - 291 с.

13. Степаненко П., Коваленко П. Племінна птиця України / Інформаційний щомісячник «Пропозиція». - 2009. - № 1. - C.36-39.

14. Файоль А. Общее и промышленное у управление.- М.: Республика, 1992. - 349 с.

15. Шибаєва Н.В. Особливості економічної поведінки суб'єктів господарювання в умовах ринкової трансформації економіки: автореф. дис.. канд. екон. наук: 08.01.01 Харківський національний університет ім. В.Н. Каразіна. - Х., 2002. - 16 c.

16. http://slovopedia.org.ua

17. https://uk.wikipedia.org/wiki

\title{
АНАЛІЗ ЛОГІСТИЧНИХ ПРОЦЕСІВ ВІЙСЬКОВИХ ПІДРОЗДІЛІВ НАЦІОНАЛЬНОЇ ГВАРДІЇ УКРАЇНИ
}

\author{
Черкашина М.В., завідувач кафедри (НАНГУ)
}

У даній статті подано методики аналізу логістичних проиесів військових підрозділів Національної гвардї Украӥни. В роботі здійснено формальний опис множини стратегічних переваг (установок) військових підрозділів Національної гвардіі України стосовно організації системи логістики. В статті запропонована ігрова

(C) Черкашина M.B.

Вісник економіки транспорту і промисловості № 69, 2020 
модель, за допомогою якої вирішується задача визначення даних параметрів стратегії організації системи логістики військового підрозділу з урахуванням можливостей партнерів за логістичним ланцюжком. Запропоновано неантагоністичну диференціальну гру військового підрозділу $і$ його компаній-партнерів, за допомогою якої визначається розмір вкладень військового підрозділу на покриття вартості його участі в логістичній мережі та обсяг резервних запасів.

Ключові слова: логістичні процеси, військовий підрозділ, компанія-партнер, ігрова модель, стратегічні переваги, логістична мережа

\title{
АНАЛИЗ ЛОГИСТИЧЕСКИХ ПРОЦЕССОВ ВОЕННЫХ ПОДРАЗДЕЛЕНИЙ НАЦИОНАЛЬНОЙ ГВАРДИИ УКРАИНЫ
}

\author{
Черкашина М. В., заведующая кафедры (НАНГУ)
}

В данной статье представлена методика анализа логистических процессов военных подразделений Национальной гвардии Украины. В работе осуществлено формальное описание множества стратегических преимуществ (установок) военных подразделений Национальной гвардии Украинь относительно организации системь логистики. В статье предложена игровая модель, с помощью которой решается задача определения данных параметров стратегии организации системы логистики военного подразделения с учетом возможностей партнеров по логистической цепочкой. Предложено неантагонистические дифференциальную декабря воинского подразделения и его компаний-партнеров, с помощью которой определяется размер вложений военного подразделения на покрытие стоимости его участия в логистической сети и объем резервных запасов.

Ключевые слова: логистические процессы, военное подразделение, компанияпартнер, игровая модель, стратегические преимущества, логистическая сеть

\section{ANALYSIS OF LOGISTICAL PROCESSES OF THE NATIONAL GUARDS OF UKRAINE}

\section{Cherkashyna M., Head of the Department (NANGU)}

In this article the methods of analysis of logistic processes of military units of the National Guard of Ukraine are presented. The paper describes a formal description of the many strategic advantages (installations) of the military units of the National Guard of Ukraine regarding the organization of the logistics system. The article proposes a game model, which solves the problem of determining the parameters of the strategy of organizing a system of logistics of the military unit, taking into account the capabilities of partners in the logistics chain. The model under development belongs to the class of simulation nonantagonistic differential games "player - inanimate nature", where the latter are partners of the company along the technological chain. The work of the model is to determine the parameters proposed in the article of the motorcade, the optimal values of which are selected as a result of the implementation of a certain mechanism for reconciling the benefits of the military unit and partner companies on the logistics chain based on utility functions. In the context of logistics chains, matching partners' benefits is especially relevant because of the high level of uncertainty associated with the uncertainty of consumer reactions to the results of joint activities, the large number of mortgage payments between partners, the high cost of the technological platform for the implementation of collective support services. and its

Вісник економіки транспорту і промисловості № 69, 2020 
partner companies to determine the size of the military unit's investment in war coverage spine of his participation in the logistics network and the amount of the reserve stocks. The paper indicates that in the process of functioning of the logistics chain in order to optimize the commercial interaction of partners, it is necessary to coordinate decisions based on the already identified strategic advantages of members of the logistics community and redistributed in the event of possible failures of functions. For this purpose, in the article, similarly to the processes in production and economic systems, the coordination problem is described by fuzzy models, on the basis of which local vector optimization problems are solved.

Key words: logistics processes, military unit, partner company, game mode, strategic advantages, logistics network

\section{Постановка}

Боєздатність військових підрозділів Національної гвардії України та ефективне виконання поставлених командуванням завдань залежить перш за все від належного матеріально-технічного, тилового та інформаційного забезпечення військових формувань В свою чергу, належне забезпечення військових підрозділів необхідними видами ресурсів обумовлюється наявністю цілеспрямованої та ефективної організації системи логістики.

3 позицій наукової площини актуального значення в цьому сенсі набуває аналіз логістичних процесів військових підрозділів Національної гвардії України та вивчення стратегічних переваг військового формування з позицій досягнення належного рівня організації системи логістики.

Аналіз останніх досліджень $\boldsymbol{i}$ публікацій. Дослідження характерних особливостей та динаміки логістичних процесів у сучасних умовах господарської діяльності розкрито у роботах Соколовського С.А., Науменко М.О., Черкашиної М. В, Грабовського С.М. та iн. дослідників. Зокрема питанням застосування електронних платіжних систем присвячені роботи [1-4]. Особливості управління якістю логістики організацій подані в дослідженнях [5-10]. Аналіз особливостей управління інформаційними потоками логістичних процесів розглянуто у наукових статтях [11-12].
Виділення невирішених частин загальної проблеми. Однак на сьогодні в спеціалізованій літературі відсутній методичний підхід 3 економікоматематичними моделями аналізу логістичних процесів військових підрозділів Національної гвардії України.

Метою даної статmі є розробка методики аналізу логістичних процесів військових підрозділів Національної гвардії України.

Викладення основного матеріалу дослідження. Командування військових підрозділів Національної гвардії України повинно визначити множину своїх стратегічних переваг (установок), які можна задати у вигляді наступного кортежу:

$$
\mathrm{RV}, \mathrm{OZ}, \mathrm{KS}>\text {, }
$$

$$
\mathrm{S}=<\mathrm{OS}
$$

де OS - кількість комерційних операцій (в одиницях), які передаються реалізуються в рамках логістичних процесів; RV - розмір вкладення конкретної компанії-партнера військового підрозділу (в гривнях) на покриття вартості участі в логістичному співтоваристві; OZ - обсяг резервних запасів постачальницько-збутової мережі військового підрозділу (в гривнях); KS кількість спільно реалізованих логістичних проектів військового підрозділу 3 компаніями-партнерами(в одиницях).

Задача визначення даних параметрів стратегії організації системи 
логістики військового підрозділу 3 класу імітаційних неантагоністичних урахуванням можливостей партнерів за диференціальних ігор «гравець - нежива логістичним ланцюжком може бути природа», де останньою виступають вирішена з використанням ігрової моделі, партнери компанії за технологічним у якій елементами множини стратегій ланцюжком.

виступають компоненти кортежу (1). Загальне подання гри має такий Модель, що розроблюється, належить до вигляд (рис. 1):

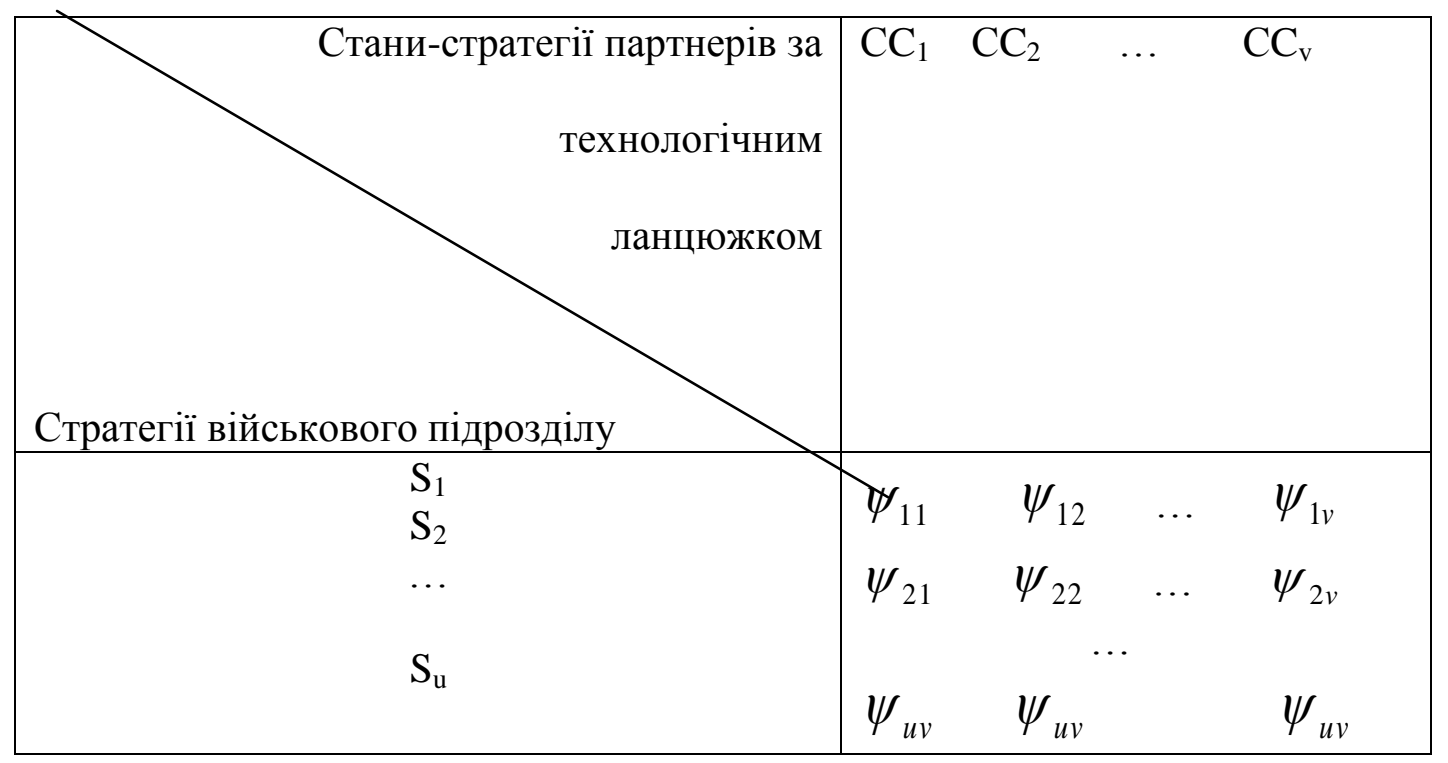

Рис. 1. Загальний вигляд ігрової моделі «гравещь - нежива природа»

Для k-ої компанії-гравця задаються:

1) множина стратегій $\mathrm{S}_{\mathrm{u}}=\left\{\mathrm{x}_{1}\right.$, $\left.\mathrm{x}_{2}, \ldots, \mathrm{x}_{\mathrm{u}}\right\}$, які відображають систему цілей взаємодії військового підрозділу 3 компаніями-партнерами в рамках технологічного ланцюжка;

2) критерій ефективності (функція корисності) $\psi\left(\mathrm{x}_{1}, \mathrm{x}_{2}, \ldots, \mathrm{x}_{\mathrm{u}}\right)$ вибору $\mathrm{k}$-им гравцем раціональних параметрів.

Робота моделі полягає у визначенні параметрів кортежу (1), оптимальні значення яких вибираються в результаті реалізації певного механізму узгодження переваг військового підрозділу та компаній-партнерів за логістичним ланцюжком на основі функцій корисності. В умовах логістичних ланцюжків узгодження переваг партнерів є особливо актуальним внаслідок високого рівня невизначеності, пов'язаної 3 невідомістю реакції споживачів на результати спільної діяльності, великою кількістю заставних розрахунків між партнерами, високою вартістю технологічної платформи для здійснення колективних допоміжних сервісів.

Робота моделі починається 3 визначення обсягу комерційних операцій компаній-партнерів і кількості проектів, виходячи $з$ доцільності (корисності) даного процесу для обох сторін. Функція корисності для k-ої зовнішньої структури полягає в максимізації сумарної виручки:

$$
\psi_{1 k}=\sum_{r=1}^{R} O S_{r} \cdot O P_{r} \rightarrow \max _{\mathrm{OS}_{\mathrm{r}}},
$$

де ОР - обсяг продажів (в гривнях); $r$ - індекс цільового сегмента.

Для військового підрозділу функція корисності складається в зниженні питомої вартості функціонування ланки ланцюжка 3 k-им партнером у загальному бюджеті постачальницько-збутової мережі, що може знизити розмір вкладення військового підрозділу в співтовариство в цілому. Формально ця умова записується у вигляді мінімізації виразу наступного виду: 


$$
\psi_{10}=\frac{\sum_{r=1}^{R} S Z_{r} \cdot K S_{r}}{B S} \rightarrow \min _{K S_{r}},
$$

де SZ - витрати на здійснення електронного обміну даних (EDI) i обслуговування системи логістики; BS величина бюджету постачальницькозбутової мережі.

Корисність всього логістичного ланцюжка в цілому може бути визначена характеристичною функцією гри, що для розглянутої моделі має вигляд:

$$
\psi_{1}=\frac{\sum_{r=1}^{R} \sum_{k=1}^{K}\left(O S_{r k} \cdot O P_{r k}-S Z_{r k} \cdot K S_{r k}\right)}{B S} \rightarrow \max _{O S_{r}, K S_{r}}
$$

Обмеженнями моделі являються:

$$
\begin{aligned}
& \sum_{k=1}^{K} O S_{r k} \leq O T, r \in \mathrm{R} \\
& \sum_{\mathrm{r}=1}^{\mathrm{R}} \mathrm{KS}_{\mathrm{rk}} \leq \frac{\mathrm{ER}}{\mathrm{OK}}, k \in K,
\end{aligned}
$$

де ОТ - загальний обсяг (у вартісному вираженні) комерційних операцій, реалізованих компанієюпартнером; ER - величина сукупного попиту цільового сегменту (в гривнях); ОК - обсяг оборотного капіталу (в гривнях).

Розмір вкладень військового підрозділу на покриття вартості його участі в логістичній мережі та обсяг резервних запасів можуть бути визначені в результаті вирішення наступної неантагоністичної диференціальної гри військового підрозділу і його компаній-партнерів.

Командування військового підрозділу прагне знизити свої витрати, пов'язані з його участю в логістичному ланцюжку, що знаходить своє вираження в мінімізації виразу:

$$
\psi_{20}=\frac{R V}{O K}+\frac{O Z}{S M} \rightarrow \min _{R V, O Z},
$$

де $\mathrm{SM}$ - загальна вартість системи матеріально-технічного забезпечення в умовах ऑiі наскрізної автоматизованої реалізації.

K-ий партнер військового підрозділу за логістичним ланцюжком, бажаючи максимізувати обсяг своїх резервних запасів RZ у заданій пропорції, прагне мінімізувати вираз:

$$
\psi_{2 \mathrm{k}}=\frac{\mathrm{RZ}}{\mathrm{BS}} \rightarrow \min _{\mathrm{RZ}},
$$

Критерій ефективності в цьому випадку буде мати вигляд:

$$
\psi_{2}=\frac{\mathrm{RV}}{\mathrm{OK}}+\frac{\mathrm{OZ}}{\mathrm{SM}}-\frac{\mathrm{RZ}}{\mathrm{BS}}
$$

Обмеженнями моделі являються:

$$
\begin{aligned}
& 0 \leq \mathrm{RV}<\mathrm{BS}, \\
& 0 \leq \mathrm{OZ} \leq \sum_{\mathrm{r}=1}^{\mathrm{R}} \mathrm{OP}_{\mathrm{r}} .
\end{aligned}
$$

Для описаної моделі сформуємо диференціальну гру, коли провідним гравцем $є$ командування військового підрозділу. Командування військового підрозділу вибирає своїх партнерів за логістичним ланцюжком та повідомляе їм позиційну стратегію $\mathrm{RV}^{\prime}$, що задовольняє обмеженню (8). Після цього партнер 3 умови мінімізації функції (6) визначає стратегію RZ. Задача командування військового підрозділу полягає у виборі такої стратегії RV', щоб при відповідній стратегії партнера за логістичним ланцюжком вираз (5) приймав мінімальне значення.

У процесі функціонування логістичного ланцюжка 3 метою оптимізації комерційної взаємодії партнерів необхідно здійснювати координацію рішень на основі вже визначених стратегічних переваг учасників логістичного співтовариства та перерозподілених на випадок можливих збоїв функцій. Аналогічно процесам у виробничо-економічних системах [6] задача координації може бути описана нечіткими моделями, на базі яких вирішуються локальні задачі векторної оптимізації.

Командування військового підрозділу виробляє нечіткі координуючі сигнали $\varphi_{k}$, які надходять до k-ого учасника ланцюжка та забезпечують такі співвідношення показників учасників, які 
максимізують функцію $\Phi_{0}, \quad$ при процесів військових підрозділів обмеженнях $\Phi_{k}(\tilde{p}, \varphi) \geq P O_{k}$.

$$
\Phi_{0}=\sum_{k=1}^{K} \varphi_{k} \tilde{p}_{k} \rightarrow \max _{p_{k}}
$$

де $\tilde{p}_{k}-$ показники - тактичні параметри компаній-партнерів за ланцюжком; $\mathrm{PO}_{\mathrm{k}}-$ прийняті в логістичному ланцюжку обмеження за основними показниками k-ого учасника (кількість таких обмежень відповідає числу показників).

Показниками партнерів за логістичним ланцюжком будуть виступати наступні лінгвістичні змінні:

$\tilde{p}_{1}$ - інтенсивність використання виробничих потужностей;

$\tilde{p}_{2}$ - рівень стандартизації бізнеспроцесів;

$\tilde{p}_{3} \quad$ - масштаб маркетингових ініціатив на ринку;

$\tilde{p}_{4}$ - рівень використання електронних платіжних систем;

$\tilde{p}_{5}$ - величина доступу до ринку на основі використання інтернет-каналів.

Дані лінгвістичні змінні можуть бути описані наступних терм-множинами:

$\tilde{p}_{1}=$ виисока, середня по ланцюжку, низька $\}$;

$\tilde{p}_{2}=$ \{переважна стандартизація, часткова стандартизація, незначна стандартизація\};

$\tilde{p}_{3}=\{$ значний, середній по ланцюжку, низький\};

$\tilde{p}_{4}=$ \{високий, середній по ланцюжку, низький $\}$;

$\tilde{p}_{5}=$ пповне охоплення ринку, охоплення переважної частки ринку, частковий доступ лише до деяких сегментів $\}$.

Висновок. Таким чином, запропонована аналізу логістичних
Національної гвардії України містить визначення множини стратегічних переваг (установок) військових формувань, визначення основних параметрів стратегії організації системи логістики військового підрозділу 3 урахуванням можливостей партнерів за логістичним ланцюжком i обчислення розміру вкладень військового підрозділу на покриття вартості його участі в логістичній мережі та обсяг резервних запасів.

Подальшим напрямком дослідження може стати розробка методики узгодження параметрів системи логістики військових підрозділів Національної гвардії України.

\section{ПЕРЕЛІК ВИКОРИСТАНИХ ДЖЕРЕЛ}

1. Hrabovskyi Y., Yevsyeyev O. Development of methodological principles of support-preservation engineering work. Технолоічний аудит і резерви виробництва. 2018. №2/2. C. 43-49

2. Hu C., Yang Z, Mingjing G. AHP and CA Based Evaluation of Website Information Service Quality: An Empirical Study on High-Tech Industry Information Center Web Portals. Journal Service Science \& Management. 2009. № 3. P. 168-180 DOI: https://doi.org/10.4236/jssm.2009.23020

3. Summary of the Methodology for assesing the Dynamics and Impacts of Electronic Commerce . OECD WPIE Ad Hoc Technucal Expert Group. 2004. P.12

4. Naumenko M., Hrabovskyi Y., Elaboration of methodology for designing a publishing and printing web portal. EasternEuropean Journal of Enterprise Technologies. 2018. № 2/2 (92), pp. 14 - 22. DOI: 10.15587/1729-4061.2018.126305

5. Hrabovskyi Y., Brynza N, Vilkhivska O. Development of information visualization methods for use in multimedia applications. EUREKA: Physics and Engineering. 2020. № 1. Рp. 3 - 17,

6. Науменко М.О. Вдосконалення управління якістю продукції 
високотехнологічних підприємств. Вісник економіки транспорту $i$ промисловості. 2018. № 62. С. 335-342.

7. Hrabovskyi Y., Fedorchenko V., Development of the optimization model of the interface of multimedia edition. EUREKA: Physics and Engineering. 2019. № 3. Pp. 3 12. DOI: $10.21303 / 2461-4262.2019 .00902$

8. Pushkar O., Hrabovskyi Y. Methodology for developing an intelligent user interface for educational publications in the e-learning system. Development Management. 2019. № 17(3. P. 23-34. Doi:10.21511/dm.17(3).2019.03

9. Каличева Н.Є., Маслова В.О. Логістичні підходи, як основа раціональної організації виробничого процесу на підприємстві. Вісник економіки транспорту і промисловості. 2014. № 47. C. 83 - 86.

10. Каличева Н.Є., Копачевська Ю. А. Вплив логістики на розвиток підприємств малого бізнесу в сучасних умовах господарювання. Науковий вісник УжНУ. Серія: Міжнародні економічні відносини та світове господарство. 2018. Випуск 20. Ч. 2. С. 11 - 14.

11. Соколовський С. А, Науменко М. О. Аналіз особливостей управління інформаційними потоками логістичних процесів підрозділів Національної гвардії України. ScienceRise. 2018. № 2. С. 19-21.

12. Каличева Н. Є. Проблеми та перспективи впровадження інформаційних технологій у вітчизняній транспортній сфері. Сучасна економіка: актуальні проблеми та перспективи розвитку: колективна монографія /за заг. редакцією д-ра екон. наук, професора В. В. Прохорової. Харків: «НТМТ», 2014. С. 7378.

\section{REFERENCES}

1. Hrabovskyi Y., Yevsyeyev O. (2018). Development of methodological principles of support-preservation engineering work. Technological audit and production reserves.. №2/2. C. 43-49.
2. Hu C., Yang Z, Mingjing G. AHP and CA Based Evaluation of Website Information Service Quality: An Empirical Study on High-Tech Industry Information Center Web Portals//Journal Service Science \& Management. 2009. № 3. P. 168-180 DOI: https://doi.org/10.4236/jssm.2009.23020

3. Summary of the Methodology for assesing the Dynamics and Impacts of Electronic Commerce (2004). OECD WPIE Ad Hoc Technucal Expert Group. P. 12

4. Naumenko M., Hrabovskyi Y. (2018) Elaboration of methodology for designing a publishing and printing web portal. Eastern-European Journal of Enterprise Technologies.. № 2/2 (92). Pp. $14-$ 22. DOI: $10.15587 / 1729-4061.2018 .126305$

5. Hrabovskyi Y., Brynza N, Vilkhivska O. (2020). Development of information visualization methods for use in multimedia applications. EUREKA: Physics and Engineering. № 1. pp. 3 - 17.

6. Naumenko M. O. (2018). Vdoskonalennya upravlinnya yakistyu produkciyi vy`sokotexnologichny`x pidpry`yemstv. [Improvement of product quality management of high-tech enterprises. Bulletin of the Economics of Transport and Industry. No. 62, pp. $335-342$.

7. Hrabovskyi Y., Fedorchenko V. (2019). Development of the optimization model of the interface of multimedia edition. EUREKA: Physics and Engineering, № 3, pp. 3 - 12, DOI: 10.21303/2461-4262.2019.00902

8. Pushkar O., Hrabovskyi Y. (2019) Methodology for developing an intelligent user interface for educational publications in the e-learning system. Development Management, № 17(3), pp. 23-34. doi:10.21511/dm.17(3).2019.03

9. Kalycheva N.Ie., Maslova V.O. (2014) Lohistychni pidkhody, yak osnova ratsionalnoi orhanizatsii vyrobnychoho protsesu na pidpryiemstvi [Logistic approaches as a basis for rational organization of production process at the enterprise]. Bulletin of Economics of Transport and Industry. No. 47. Pp. 83 - 86. 
10. Kalycheva N.Ie., Kopachevska Yu. A. (2018) Vplyv lohistyky na rozvytok pidpryiemstv maloho biznesu $\mathrm{v}$ suchasnykh umovakh hospodariuvannia. [The influence of logistics on the development of small business in modern conditions of management]. UzhNU Scientific Bulletin. Series: International Economic Relations and the World Economy. Issue 20. Part 2. Pp. 11 - 14

11. Sokolovskyi S. A., Naumenko N. A. (2018). Analiz osobly`vostej upravlinnya informacijny`my` potokamy` logisty`chny`x procesiv pidrozdiliv Nacional noyi gvardiyi Ukrayiny. [Analysis of peculiarities of management of information flows of logistic processes of units of the National Guard of Ukraine]. ScienceRise. No 2, pp. 19-21.

12. Kalicheva N.E. (2014). Problemy` ta perspekty`vy` vprovadzhennya informacijny`x texnologij u vitchy`znyanij transportnij sferi. [Problems and prospects of introduction of information technologies in the domestic transport sphere]. Suchasna ekonomika: aktual'ni problemy' ta perspekty`vy` rozvy`tku: kolekty`vna monografiya. [Modern Economics: Current Issues and Prospects for Development: A Collective Monograph]. Kharkiv: NTMT, pp. 73-78.

\title{
УДК 656.13.033.1
}

\section{МЕТОДИКА ОЦІНЮВАННЯ ЕФЕКТИВНОСТІ ЛОГІСТИКИ ВИСОКОТЕХНОЛОГІЧНОЇ ОРГАНІЗАЦЇ̈}

\author{
Чухлата Ж.Г., ст. викладач (НАНГУ)
}

\begin{abstract}
У даній статті подано методику оцінки ефективності логістики високотехнологічної організачіі в сучасних умовах інформаційної економіки. Запропонована система показників ефективності логістичних прочесів. В роботі констатується, щзо управління ризиками логістичних процесів організації доцільно здійснювати в розрізі їх основних класифікаційних груп. Пропонуються складові стабілізуючого механізму для ризикових точок ланцюжків логістики. Подальшим напрямком даного дослідження може стати методика управління комериійними транзакиіями високотехнологічної організації в логістичному ланцюжку стратегічних партнерів.
\end{abstract}

Ключові слова: логістика, ефективність, високотехнологічна організація, оцінювання, управління ризиками, логістичні процеси

\section{МЕТОДИКА ОЦЕНКИ ЭФФЕКТИВНОСТИ ЛОГИСТИКИ ВЫСОКОТЕХНОЛОГИЧНЫХ ОРГАНИЗАЦИИ}

\author{
Чухлатая Ж.Г., ст.преподаватель (НАНГУ)
}

В данной статье представлена методика оценки эффективности логистики высокотехнологичной организаџии в современных условиях информаџионной экономики. Предложенная система показателей эффективности логистических процессов. В работе констатируется, что управление рисками логистических процессов организации иелесообразно осуществлять в разрезе их основных 